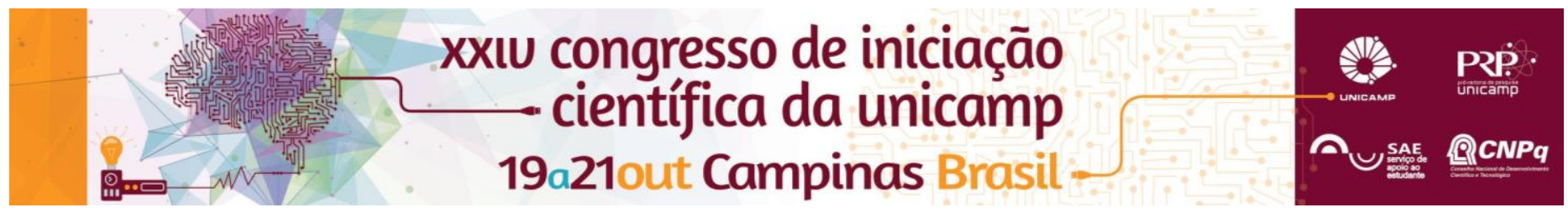

\title{
Os impactos da financeirização global na evolução da política fiscal
}

\author{
Ariel F. Leite*, Geraldo Biasoto.
}

\section{Resumo}

A despesa pública é uma questão frequentemente em voga no Brasil. Seu caráter crescente se deve à obrigatoriedade de muitas despesas, que não podem ser contingenciadas. Nas despesas primárias, existe uma aceleração do crescimento do gasto devido ao aumento real do salário-mínimo na última década, conjuntamente com o da expectativa de vida da população - que afetam as despesas com pessoal, previdência e a maioria dos benefícios sociais (direta ou indiretamente). Além disso, ampliaram-se de forma considerável as despesas discricionárias, nos últimos anos, devido ao orçamento dos ministérios e os programas sociais e de investimento dos governos petistas. Outro aspecto é o das despesas financeiras, que têm grande peso no orçamento nacional, e tendem a continuar crescendo se mantida a política de elevação da taxa Selic do Banco Central.

Palavras-chave:

Despesa, orçamento, financeirização

\section{Introdução}

O equilíbrio fiscal é um aspecto essencial para o governo de qualquer país. $O$ excesso de despesas pode gerar pressão inflacionária e aumentar o endividamento. Sendo assim, a elaboração de um bom orçamento é um aspecto essencial, tanto para a organização e controle das despesas, como para a transparência destas para o público geral.

Isto posto, procura-se analisar a evolução das despesas fiscais no período 1997-2014, com especial ênfase para os anos de governo do PT, e seus principais determinantes, assim como a execução orçamentária, observando sua organização e os contingenciamentos, que se tornaram um problema recorrente nos últimos anos desse período.

\section{Resultados e Discussão}

Para a análise das despesas do Governo Federal foram utilizados os Relatórios do Tesouro Nacional, de 1997 até 2014, e o Portal SIGA Brasil - que fornecem classificações ligeiramente distintas para estas

O orçamento brasileiro é muito rígido, havendo diversas despesas obrigatórias, que são crescentes ao longo dos anos, devido ao aumento do salário mínimo, da expectativa de vida da população e de problemas na legislação relativa a alguns benefícios. Se enquadram nesse perfil as despesas com Pessoal e Encargos Sociais, FAT, LOAS, RMV e Previdência Social.

As Outras Despesas de Custeio e Capital, que em 2014 representaram $73 \%$ das despesas de Custeio e Capital, são outro aspecto muito importante do gasto público. Esta conta inclui as despesas do PAC e Bolsa Família, que tiveram um grande crescimento desde sua criação, embora continuem a representar uma parcela pequena do gasto global, e discricionárias - destacando-se o Ministério da Saúde, Educação e do Desenvolvimento Social e Combate à Fome (que inclui as despesas do Bolsa Família).

Além disso, é necessário atentar para o fato de que as despesas financeiras - somando-se Amortização/Refinanciamento da Dívida e Juros e Encargos da Dívida - corresponderam a $45,1 \%$ do total em 2014.

Outro aspecto importante do orçamento brasileiro nos últimos anos foram os contingenciamentos. A execução de Investimentos foi apenas 23,1\% em 2014. Quando se observa o orçamento da ótica dos programas isso se torna um problema ainda maior, havendo muitos que tem execução a baixo de $50 \%$ - gerando despesas de pessoal sem a capacidade de executar de forma eficiente o que foi planejado. O contingenciamento dos últimos anos tem gerado muitos pagamentos atrasados, que entram no orçamento do ano seguinte como Restos a Pagar, distorcendo-o.
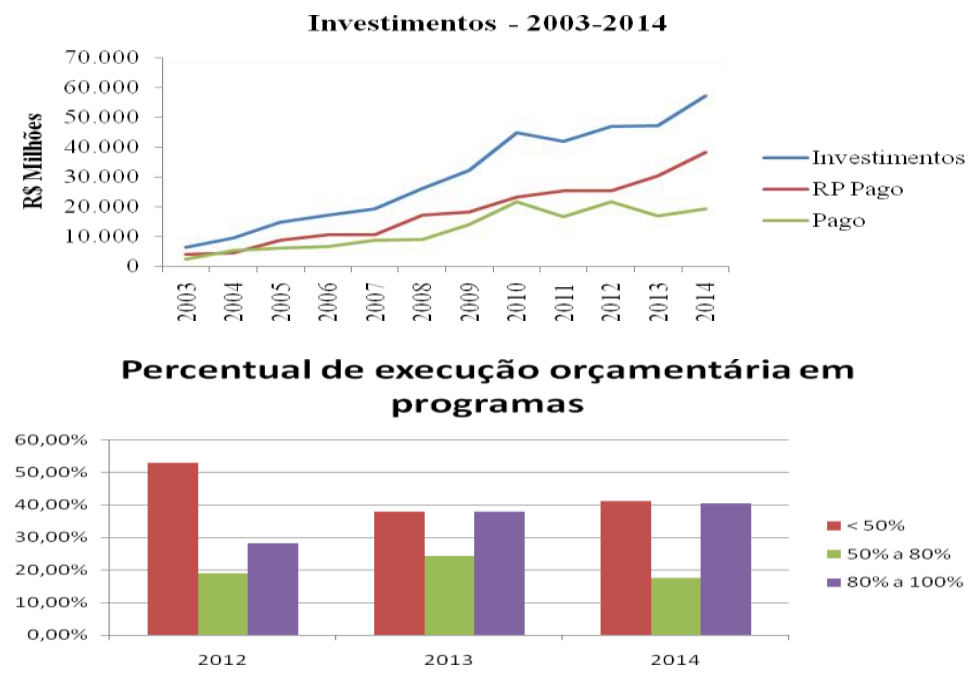

Fonte: Siga Brasil (2015). Elaboração própria.

\section{Conclusões}

A rigidez orçamentária brasileira torna pequena a margem de manobra do governo para elaboração de novos programas, um dos fatores que colocou o PAC e o Bolsa Família como principais alvos apontados como comprometedores da saúde fiscal. É necessário ressaltar a importância desses e outros programas, que visam o desenvolvimento socioeconômico, de capital físico e humano

Já os contingenciamentos evidenciam uma desorganização na elaboração do orçamento, que diminuindo a sua transparência, além de comprometerem o funcionamento de muitos programas. Isso evidencia as prioridades do governo, que em 2014 deu primazia às despesas financeiras em prol do investimento. 